\title{
Nordic Programme for Co-operation on Energy Policy 2018-2021
}

(1) Nordic Council of Ministers 
Nordic Programme for Co-operation on Energy Policy 2018-2021

ANP 2017:770

ISBN 978-92-893-5208-6 (PRINT)

ISBN 978-92-893-5209-3 (PDF)

ISBN 978-92-893-5210-9 (EPUB)

http://dx.doi.org/10.6027/ANP2017-770

(c) Nordic Council of Ministers 2017

Layout: Gitte Wejnold

Cover Photo: Unsplash.com

Print: Rosendahls

Printed in Denmark

\section{Nordic co-operation}

Nordic co-operation is one of the world's most extensive forms of regional collaboration, involving Denmark, Finland, Iceland, Norway, Sweden, the Faroe Islands, Greenland, and Åland.

Nordic co-operation has firm traditions in politics, the economy, and culture. It plays an important role in European and international collaboration, and aims at creating a strong Nordic community in a strong Europe.

Nordic co-operation seeks to safeguard Nordic and regional interests and principles in the global community. Shared Nordic values help the region solidify its position as one of the world's most innovative and competitive.

\section{Nordic Council of Ministers}

Nordens Hus

Ved Stranden 18

1061 København $\mathrm{K}$

www.norden.org

Download Nordic publications at www.norden.org/nordpub 


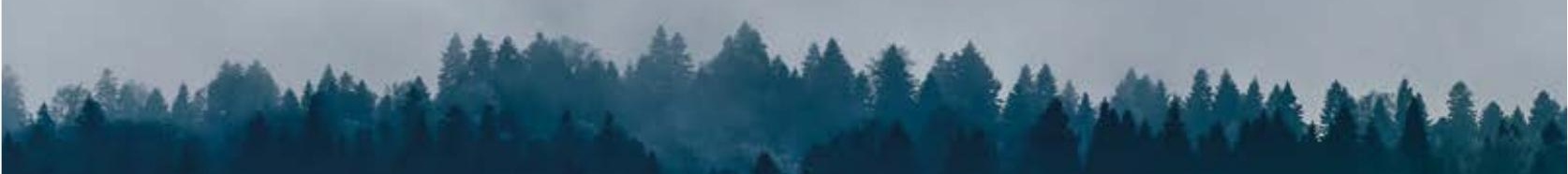

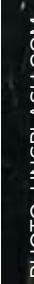





\section{CONTENTS}

$\begin{array}{ll}\text { Foreword } & 6\end{array}$

$\begin{array}{ll}\text { Introduction } & 8\end{array}$

$\begin{array}{ll}\text { Objectives and priorities } & 12\end{array}$

$\begin{array}{ll}\text { The Nordic electricity market } & 14\end{array}$

$\begin{array}{ll}\text { Renewable energy } & 18\end{array}$

$\begin{array}{lr}\text { Energy efficiency } & 20\end{array}$

Exchanges of information and dialogue about Nordic countries' energy policies and strategies $\quad 22$

$\begin{array}{ll}\text { Energy research } & 23\end{array}$

The Nordic Region in Europe (EU/EEA) and other international co-operation 25

Horizontal themes $\quad 28$

Energy-related transport aspects 28

Nordic energy co-operation in the Faroe Islands, Greenland and Åland 30

Links to horizontal strategies 30

Appendix A

The organisation of the sector $\quad 32$

Appendix B

Strategic review of the energy sector 33

Appendix C

Strategic mandate for Nordic Energy Research (NEF) 34 


\section{FOREWORD}

Nordic co-operation on energy is already strong and vibrant, and this new programme identifies priorities for the period 2018-2021. The single Nordic electricity market, renewable energy, energy efficiency and research will continue to be important elements of the work.

The preparatory work leading up to the new programme included a strategic review of Nordic energy co-operation conducted by Jorma Ollila. The review proposed important and specific recommendations, and we would like to thank Ollila for a solid piece of work. His input has been invaluable in our work to sketch out the road ahead.

In the Nordic Region, we will continue to pay attention to the fact that the EU has stepped up work on policy development and new regulations as part of its ambition to construct an Energy Union. The Nordic countries are affected differently by this work and have different interests in the energy sector, but we can also benefit from working together to influence the negotiation and implementation process in the EU/EEA. Continuing to work closely together on European issues is a prerequisite for good Nordic regional co-operation on energy. The new programme seeks to scale up our collaboration on EU/EEA energy issues.

It is important that all Nordic networks and agencies exert influence where we have shared interests. We must learn from each other whenever we identify potential synergies in the implementation of EU policies and regulations. The Nordic countries have a long and good tradition of working together in the electricity market. This co-operation takes place at different levels, between different actors and, increasingly, within a European 
framework. The new programme continues to pursue the vision of a close working relationship on electricity in the Nordic Region.

The programme also continues to place great emphasis on exchanging information on energy policy as we move toward 2030. As neighbours, It is important that the Nordic countries keep each other informed of important development trends and decisions on energy policy.

Our Nordic countries will continue to work closely together on research, development and technology in the energy sector. Together, we can continue to present positive solutions to Europe and the rest of the world to the challenges of the future in a whole range of aspects of renewable energy, energy efficiency, transport and electro-mobility. We must continue to facilitate projects in Greenland, the Faroe Islands and Åland.

We believe that both Europe and the world need a Nordic Region that works together to pursue security of supply, an energy market that operates smoothly, sustainable growth and the prosperity of the people of the Region.

Terje Søviknes

Minister of Petroleum and Energy, Norwegian Presidency 2017 


\section{Introduction}

The Nordic countries have established strong and vibrant regional co-operation on energy, exemplified by the single electricity market and based on the ambition of a sustainable energy system in the Nordic Region.

As part of the overall process of reforming Nordic co-operation, the energy sector commissioned a strategic review that analysed and put into perspective the opportunities for developing energy co-operation over the next 5-10 years. Jorma Ollila, former CEO of Nokia, conducted the review, which was a highly useful source of inspiration when drawing up this programme.

The programme for 2018-2021 has been designed on the basis of input from the strategic review and experience from previous co-operation.

Ollila's recommendation of a clear vision has been taken on board and provides the overall framework for the objectives for co-operation on energy policy.

The Nordic countries talk about more and more energy-policy challenges together. Despite national differences in terms of energy resources and the way in which the energy sectors are organised, there is significant Nordic interest in working together to influence the processes involved in the ongoing Europeanisation and globalisation of energy policy. The Nordic countries are in a stronger position when they reconcile their positions on individual issues. This position is further strengthened when they keep each other informed of their views and their proposed solutions to energy policy challenges at national, regional, European and global level.

EU processes and energy policy initiatives have an impact on the Nordic Region. This applies to all of the Nordic countries, whether they are member states or part of the EEA. The ambition of developing a European Energy Union - along with related proposals that are currently being developed and implemented - is expected to be crucial to the Nordic countries' future work on energy policy.

Nordic energy co-operation also plays a part in relevant intersectoral projects and programmes at Nordic and international level. A good example of a Nordic initiative at international level is the joint Nordic hosting, along with the European Commission, of two international meetings of energy ministers in the first half of 2018: 


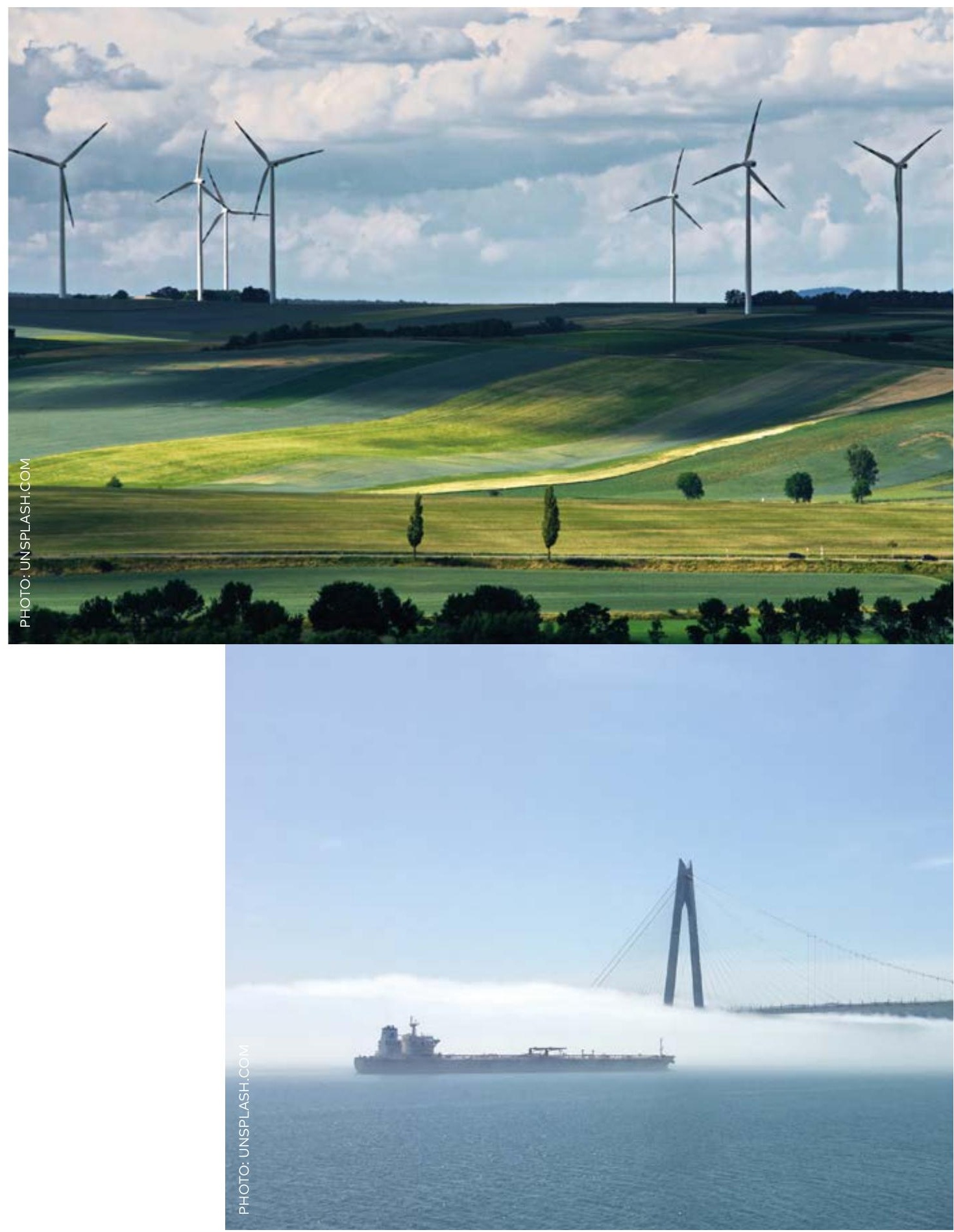


Clean Energy Ministerial 9 and Mission Innovation 3 . $^{1}$

In terms of specific energy policy initiatives, Nordic energy co-operation focuses on areas of specific political relevance and Nordic synergy, e.g. the ongoing development of the Nordic electricity market. As the Nordic energy systems become more closely integrated, new challenges continue to arise - due in part to differences between national systems or regulations. These differences should be regularly discussed and addressed within the context of Nordic co-operation. The same applies to Nordic energy co-operation's integration into European co-operation.

It is characteristic of the Nordic Region's co-operation on energy that particular challenges arise in the Faroe Islands, Greenland and Åland. The same applies to areas that are more isolated and not connected to the single electricity market. In this context, the programme for 2018-2021 will focus on achieving specific operational results as part of a strong network of energy agencies and other stakeholders.

Practical research and development projects under the auspices of Nordic Energy Research (NEF) are exploring new technologies designed to generate Nordic synergies and added value for the individual countries. The Nordic countries have different strengths in innovation and development. Along with the International Energy Agency, NEF has also drawn up the report Nordic Energy Technology Perspectives (NETP). Based on this, NEF has analysed how technical collaboration between the Nordic countries can help them achieve their national energy and climate goals by 2050 .

\footnotetext{
${ }^{1}$ The Clean Energy Ministerial (CEM) is a high-level global forum to promote policies and programmes that advance clean energy technology, to share lessons learned and best practices, and to encourage the transition to a global clean energy economy.

Mission Innovation (MI) is a global initiative to dramatically accelerate global clean energy innovation. As part of the initiative, participating countries have committed to double their governments' clean energy research and development (R\&D) investments over five years, while encouraging greater levels of private sector investment in transformative clean energy technologies.
} 


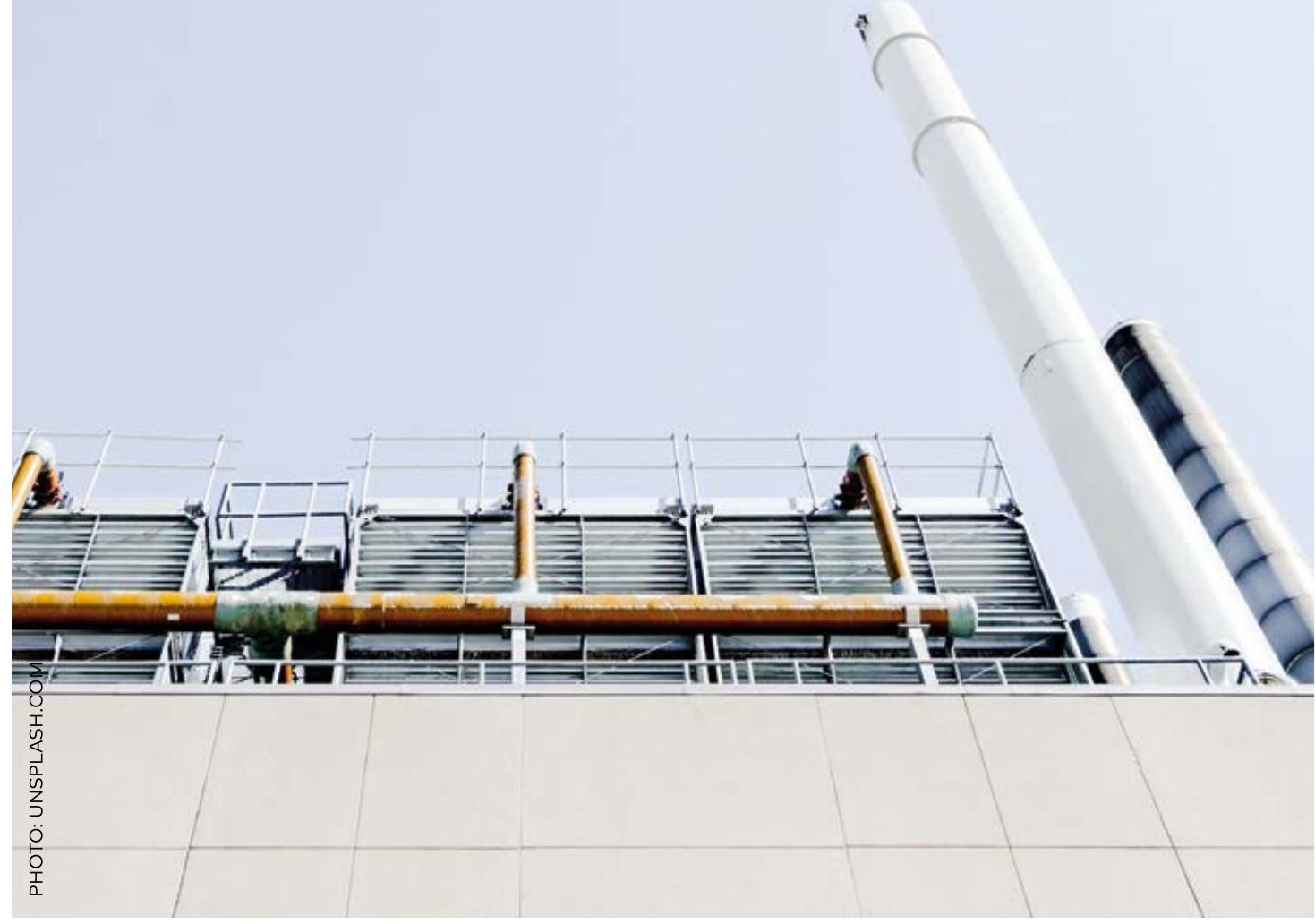




\section{Objectives and priorities}

The vision for Nordic energy cooperation is:

To develop Nordic energy systems through strong, trust-based, adaptable collaboration in order to secure the world's smartest, most integrated and intelligent low-emission green economy, characterised by high competitiveness and security of supply.

Objectives:

In line with this vision, energy cooperation must contribute to a stable and secure energy supply, a properly functioning energy market, and sustainable growth and prosperity for the people of the Nordic Region. Energy co-operation should also help the countries to achieve their ambitious national environmental and climate objectives. These include raising the global profile of Nordic positions of strength in the energy sector through the development of technical solutions that contribute to achieving climate targets.
During the period 2018-2021, Nordic energy co-operation will specifically address the following areas:

- Further development of the Nordic electricity market

- Renewable energy

- Energy efficiency

- Exchange of information and dialogue on the Nordic countries' energy policies and strategies

- Energy research and innovation, via Nordic Energy Research

- The Nordic Region in Europe, including implementation of the EU Energy Union

- Neighbouring countries, particularly the Baltic states

- Energy-related transport issues

- The energy sector in the Faroe Islands, Greenland and Åland

- Other horizontal programmes and projects, as well as international co-operation.

The following section specifies the work to be done in the areas defined above. 


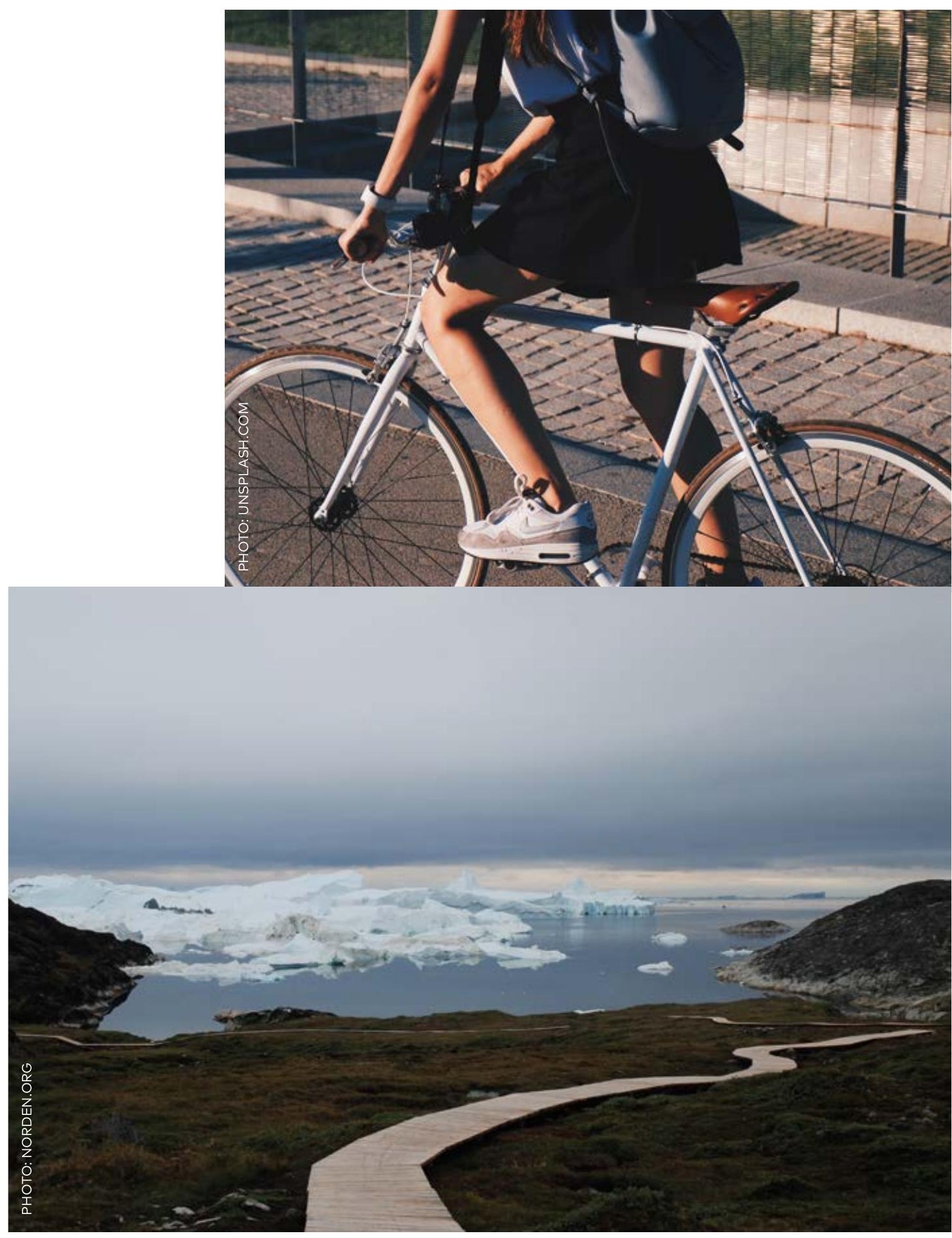




\section{The Nordic electricity market}

Norway, Sweden, Finland and Denmark make up a single Nordic electricity market. The Nordic wholesale electricity market (Nordpool) has long been an internationally recognised model for the development of cross-border electricity markets. Nordic co-operation on the electricity market has developed continuously in terms of security of supply, competition and efficiency.

One purpose of the EU Energy Union is to create a single European electricity market. One way of achieving this will be to promote measures such as new inter-connectors between the submarkets in Europe. This makes it possible to cover larger geographical areas with single markets, and the Nordic electricity market is becoming increasingly integrated with those of neighbouring countries.

\section{PRIORITIES}

The European electricity system is undergoing major changes. This is due partly to new EU legislation, ${ }^{2}$ the trend towards more decentralised and fluctuating generation of electricity from renewable sources, and more proactive and flexible consumers. Overall, this means that the Nordic co-operation on electricity will be even closer in the future, particularly in the areas described below.

\section{Function of the electricity system}

The power grid needs to be improved, and it may be necessary to adapt the current regulatory framework for the electricity market in order to integrate a greater proportion of renewable energy. The need for improvements in the different Nordic countries is partly determined by developments in the neighbouring countries. The increasing proportion of electricity from fluctuating sources (wind power, solar power, etc.) places new demands on things like balanced supply and an increased need for management and monitoring of the network. This process is also stimulating the development of smart electricity grids. There is also a growing need for storage, e.g. during periods of high production, for use during periods of lower production or high demand. Better opportunities and incentives for consumers to react to pricing can help make consumption more flexible. Smart grids make it easier to balance demand

\footnotetext{
${ }^{2}$ Negotiations on the proposals in the Commission's Winter Package had not been completed at the time this programme was adopted, hence the reference to them as proposals.
} 
over time and reduce periods of very high demand. It is important to continue to monitor developments in these areas and potentially develop Nordic strategies for doing so. The recommendations outlined in the strategic review will form part of these considerations. Gradually, and where appropriate, the electricity grid will be integrated into the heating, cooling and transport infrastructure in order to increase flexibility and enhance efficiency throughout the electricity system.

\section{Network planning and investment}

One characteristic of the Nordic electricity market is the efficient use of production resources. Bottlenecks in the Nordic grid that create major long-term differences in electricity prices should be reduced to the extent that it is socioeconomically viable. In 2010, the energy ministers decided that grid investments should only be made if they are socioeconomically viable in a Nordic perspective. Where costs and benefits are spread unevenly between the countries, the system operators should negotiate the allocation of costs and revenues between them. It is important that the Nordic transmission system operators work even more closely together in areas such as the development of socioeconomically beneficial grid planning and Nordic griddevelopment plans.

\section{New EU legislation}

The EU Commission's 2016 package of measures Clean Energy for All Europeans (also known as the Winter Package; see page 25 for more on the

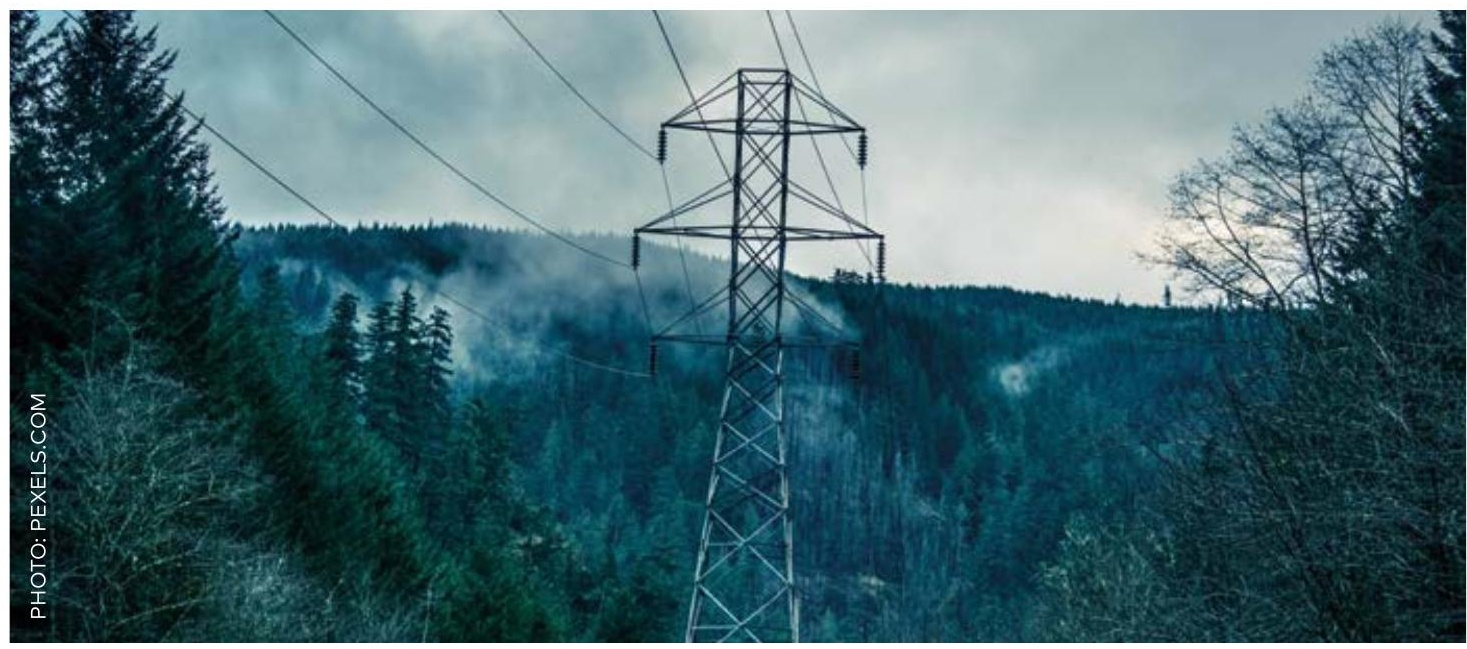




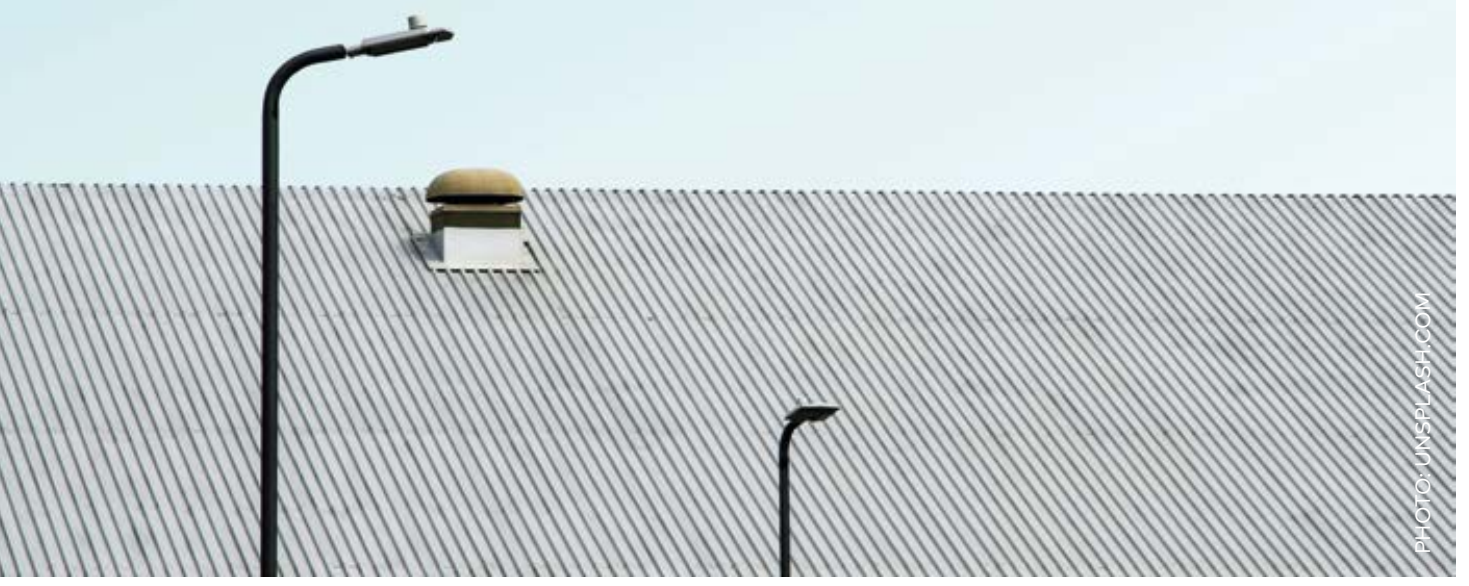


Nordic Region in Europe) contains proposals for amending regulation of the electricity market, including of the third energy package on the internal market. The Directive Concerning Measures to Safeguard Security of Electricity Supply and Infrastructure Investment will also be replaced by a new risk-preparedness in the electricity sector directive. It is important to focus on the Nordic dimension in negotiations on the new legislation, and to ensure that no regulations are passed that would act as a hindrance to the single Nordic electricity market, which is already working well. It is also important to ensure the proper balance between decisions that it is appropriate to take at EU level and those that are national matters. In several areas, the Nordic electricity market is more advanced than the rest of the EU. As a result, the Nordic countries can make a significant contribution to the development of a single European market. Making sure that this happens will be a top priority in Nordic energy co-operation. During the new programme period, work will, therefore, continue on the development of Nordic positions and communicating them to relevant bodies (e.g. the European Commission, European Parliament and the member states).

As per the Winter Package (2016), the European Commission's legislative programme focuses on regional co-operation. Specific legislation is currently being negotiated and will be implemented during the programme period (2018-2021). It is important that the Nordic Region, with its long experience of regional co-operation, contributes knowledge and advice to this process.

\section{More harmonised retail market}

A more harmonised retail market, with greater freedom of choice for consumers and stronger competition between suppliers, will make the electricity market more efficient. In 2009, the Nordic energy ministers decided to start work on a more harmonised Nordic end-user market. The agency for co-operation between the Nordic electricity regulators (NordREG) has subsequently issued recommendations for achieving a more harmonised retail market. The focus is on harmonising regulations and practices in order to reduce barriers to electricity suppliers operating simultaneously in multiple Nordic countries.

\section{Contact with market participants}

During the programme period, dialogue with market participants in the electricity market and other stakeholders will continue to be of great importance to close Nordic co-operation on energy. The form that this relationship takes will be a particular focal point during the programme period. 


\section{Renewable energy}

The Nordic countries have good access to different sources of renewable energy and are world leaders in terms of the proportion of energy from renewable sources. The proportion of energy from renewable sources varies from $30-70 \%,{ }^{3}$ significantly higher than the EU average of $16.7 \%$.

The Energy Union will have a significant impact on the development of renewable energy in the Nordic countries. Several directives concerning renewable energy for the period 20202030 are currently being revised (see pages 22 and 25 ).

\section{PRIORITIES}

\section{Co-operation on current and future EU directives}

The focus will be on Nordic co-operation on the implementation of renewable energy directives before and after 2020. Nordic interests will also be assessed in relation to $\mathrm{EU}$ renewable energy directives in the run-up to 2030. Where appropriate, Nordic positions will be adopted and communicated to relevant bodies.

\section{Support systems for renewable energy} Ambitious national policies have helped the Nordic countries achieve some of the highest proportions of energy from renewable sources in Europe. This has been achieved through measures such as support mechanisms - for example, Sweden and Norway have a joint certification system, Denmark has put offshore wind farms out to tender, and Finland has a feed-in premium scheme for renewable energy.

Exchanges of information about support mechanisms for renewable energy will remain a focus area, as will knowledge of how each country's policy affects its neighbours, e.g. via the electricity market. Other focus areas will be market developments and EU policy development.

\section{Bio-energy}

In the Nordic countries, especially Finland, Sweden and Denmark, biomass plays a bigger role in national energy supply than it does in other EU countries. Iceland, however, does not use large amounts of biomass.

\footnotetext{
${ }^{3}$ Denmark 30.8\%; Finland 39.3\%; Sweden 53.9\%; Iceland 70.2\%; and Norway 69.4\% (Eurostat 2015).
} 


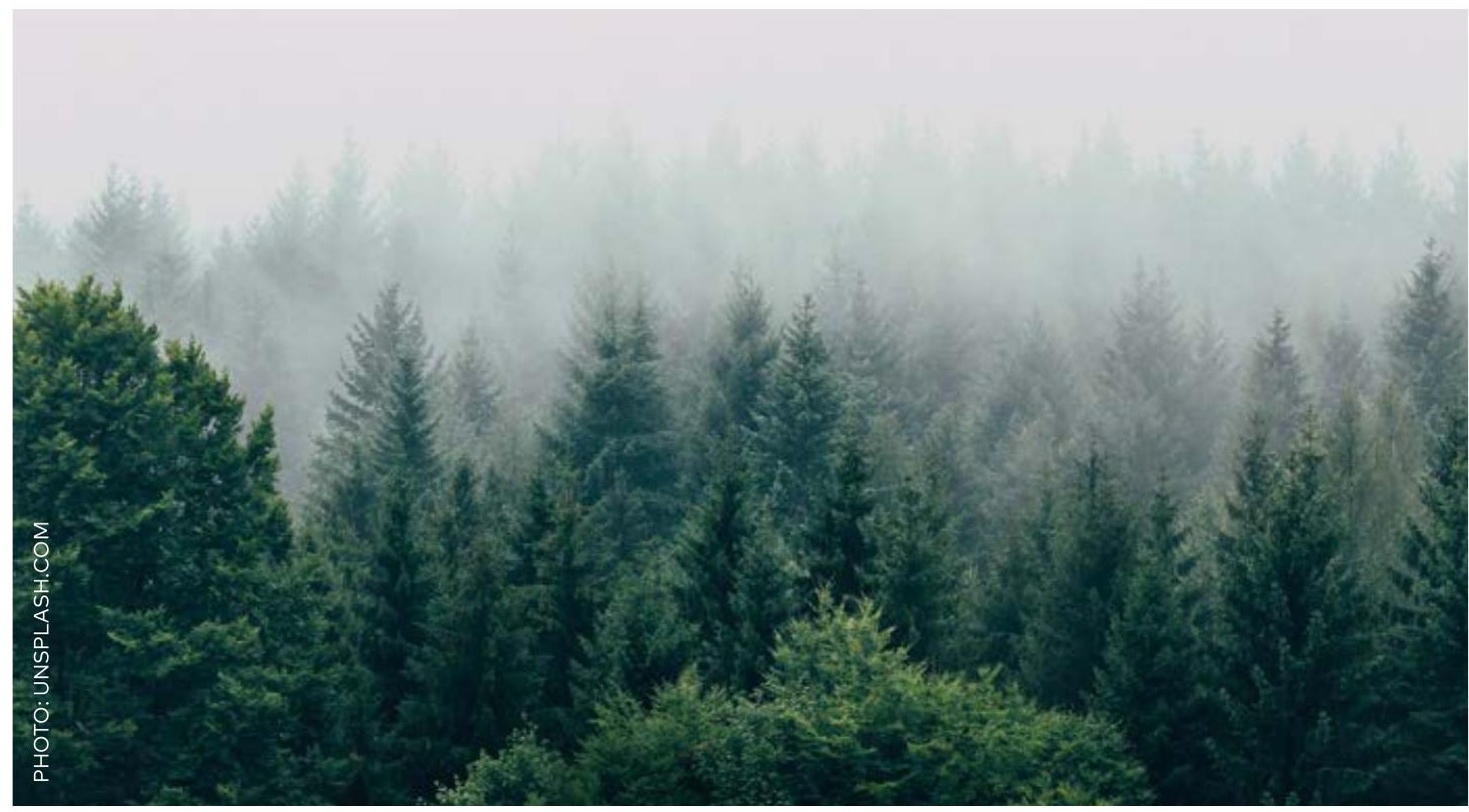

In Finland, Sweden and Norway, the biomass for energy originates from the forests and the bioenergy sector is strongly interlinked with the forestry industry. In Denmark, biomass is largely imported. In 2015, bio-energy's share of total energy in the Nordic Region was almost $20 \%$, of which biomass from forestry accounted for $42 \%$. Biomass is expected to continue to play an important role in the Nordic energy markets.

The EU Directive on Renewable Energy (RED) underlines the importance of sustainability criteria for bio-energy. ${ }^{4}$ The Nordic Region will continue to focus on developments in the EU as well as in general at the development of bioenergy in the Nordic Region.

\section{Other themes}

Opportunities for co-operation on decentralised renewable power generation will also be explored. One key focus area will be the importance of more households becoming 'prosumers' - both producers (e.g. via solar panels) and consumers of energy - including an evaluation of their impact on how the electricity market functions. This will also affect several aspects of Nordic energy co-operation, and as such the links between them will be evaluated.

\footnotetext{
${ }^{4}$ Negotiations on changes to the European Parliament' and Council's Directive on the promotion of the use of energy from renewable sources (revision of the Renewable Energy Directive) had not been completed at the time this programme was adopted. References to 'new EU legislation' refer, therefore, to the content of the Commission's proposals.
} 


\section{Energy efficiency}

Energy efficiency is one of the keys to a sustainable energy system, and helps promote greater environmental sustainability, enhanced competitiveness and security of supply. This is a Nordic position of strength, as all of the countries are investing heavily in energy efficiency at national level. Efficient use of energy has relevance for the construction and housing sector, industry, transport and manufacturing, as well as for the production and transmission of energy.

Nordic co-operation on energy efficiency helps improve knowledge and understanding of national policies in this field e.g. within heavy industry through arrangements and projects which contribute to achieving common Nordic ambitions. The EU also plays an important role in energy efficiency, through shared objectives and regulations that form the framework for national efforts. All of the Nordic countries are covered by EU/EEA legislation on energy labelling and ecodesign.

\section{PRIORITIES}

Exchanges of experience on the implementation of EU directives on energy efficiency will continue. One important area of co-operation will be the revision that the EU Commission presented in its Winter Package, e.g. the proposals for amendments to the Energy Efficiency Directive and the Energy Performance of Buildings Directive. ${ }^{5}$

While the form and content of Nordic co-operation changes all the time, its structural framework has remained more or less the same. Co-operation on energy efficiency is evolving towards networking, with the emphasis on information exchange.

\section{Nordsyn}

Nordsyn is a successful project for monitoring eco-design and energy labelling directives. Eco-design and energy labelling are derived from EU legislation, but market regulation is a national matter. The EU Commission is calling for co-operation on monitoring the market, as it is essential that all

\footnotetext{
${ }^{5}$ Negotiations on changes to the Commission's proposal for revision of the European Parliament's and the European Council's Directive 2012/27/EU on Energy Efficiency, the Commission's Proposal to the European Parliament and the Council's Directive amending Directive 2010/31/EU on the Energy Performance of Buildings had not been completed at the time this programme was adopted. References to "new EU legislation" refer, therefore, to the content of the Commission's proposals.
} 
market participants adhere to the same rules. Such harmonisation has been highly successful in the Nordic Region, where pooling resources has been shown to provide better development opportunities. The Nordsyn project involves market regulators from Denmark, Iceland, Finland, Norway and Sweden.

The project was originally based on the Nordic prime ministers' Green Growth Initiative. ${ }^{6}$ However, it has since extended into a number of sub-projects, including on the interpretation of product regulations, studies of complex products and strategically important Nordic products, measurement of the impact of market supervision and a joint online information portal. The Nordsyn group has also become an important platform that enables participants to discuss issues related to EU/EEArelated eco-design and energy labelling regulations, including general questions about future product regulations or revisions of existing ones.

Although it is not always possible to arrive at a shared Nordic position, there may be specifically Nordic perspectives on particular products that can be usefully incorporated into the negotiations at EU level.

\section{PRIORITIES}

- A new framework regulation on energy labelling, adopted by the EU in June 2017, which requires the creation of a single product database of all energy-labelled products. The regulation also involves joint information initiatives that would be of mutual benefit to the Nordic countries.

- The information initiatives will, for example, focus on the role of consumers in relation to energy efficiency and the green transition. This will involve an evaluation of the consumer's role in relation to demand response in the electricity market.

- Development of new methods and tests for joint, cost-effective market monitoring.

- Continued focus on strategic Nordic products such as heat pumps, the functioning of which is affected by the Nordic climate.

- Continued focus on market control of complex products.

\footnotetext{
6 "The Nordic Region - leading in green growth" was a Nordic Council of Ministers' priority programme launched by the prime ministers in November 2011.
} 


\section{Exchanges of information and dialogue about Nordic countries' energy policies and strategies}

The EU Commission's Winter Package included a proposal for a governance system for the Energy Union. In practice, the proposal means a new coordination system for reporting and planning across the Energy Union's five dimensions (electricity market, security of supply, energy efficiency, decarbonisation (including renewable energy and carbon capture and storage (CCS)) and R\&D/ innovation). In relation to Nordic energy co-operation, it is particularly notable that the Winter Package has a greater regional focus.
The proposals ${ }^{7}$ will be discussed in greater detail during the programme period. The discussions will include the role of Nordic co-operation in information exchanges and dialogue about the Nordic countries' energy policies and strategies. The recommendations outlined in the strategic review will form part of these considerations.

\footnotetext{
${ }^{7}$ Negotiations on the proposals in the Commission's Winter Package had not been completed at the time this programme was adopted, hence the reference to them as proposals.
} 


\section{Energy research}

Nordic Energy Research (NEF) is the platform for research and analysis under the auspices of the Nordic Council of Ministers. NEF works closely with the national energy research institutions.

The strategic mandate for NEF's work in the new programme period (see Appendix C) aims to ensure coherence between this co-operation programme, Nordic energy co-operation, NEF's articles of association and its funding document, NEF's strategy for 2018-2021 and the implementation of the Nordic Council of Ministers' budget. The strategic review of the energy sector and its results must be incorporated into thinking about the organisation's work. In general, all of NEF's activities must promote Nordic co-operation on energy, Nordic synergies and Nordic visibility.

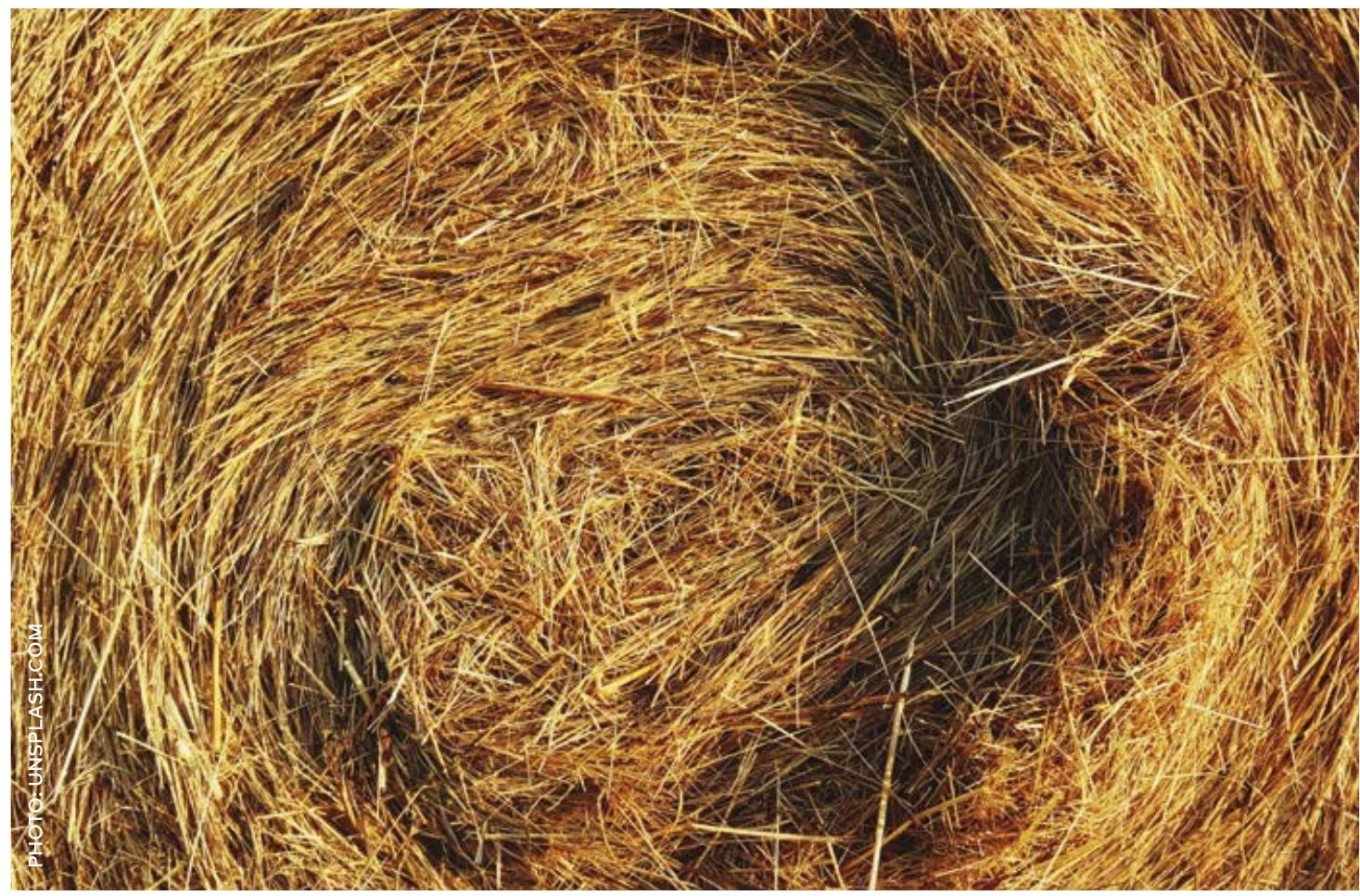




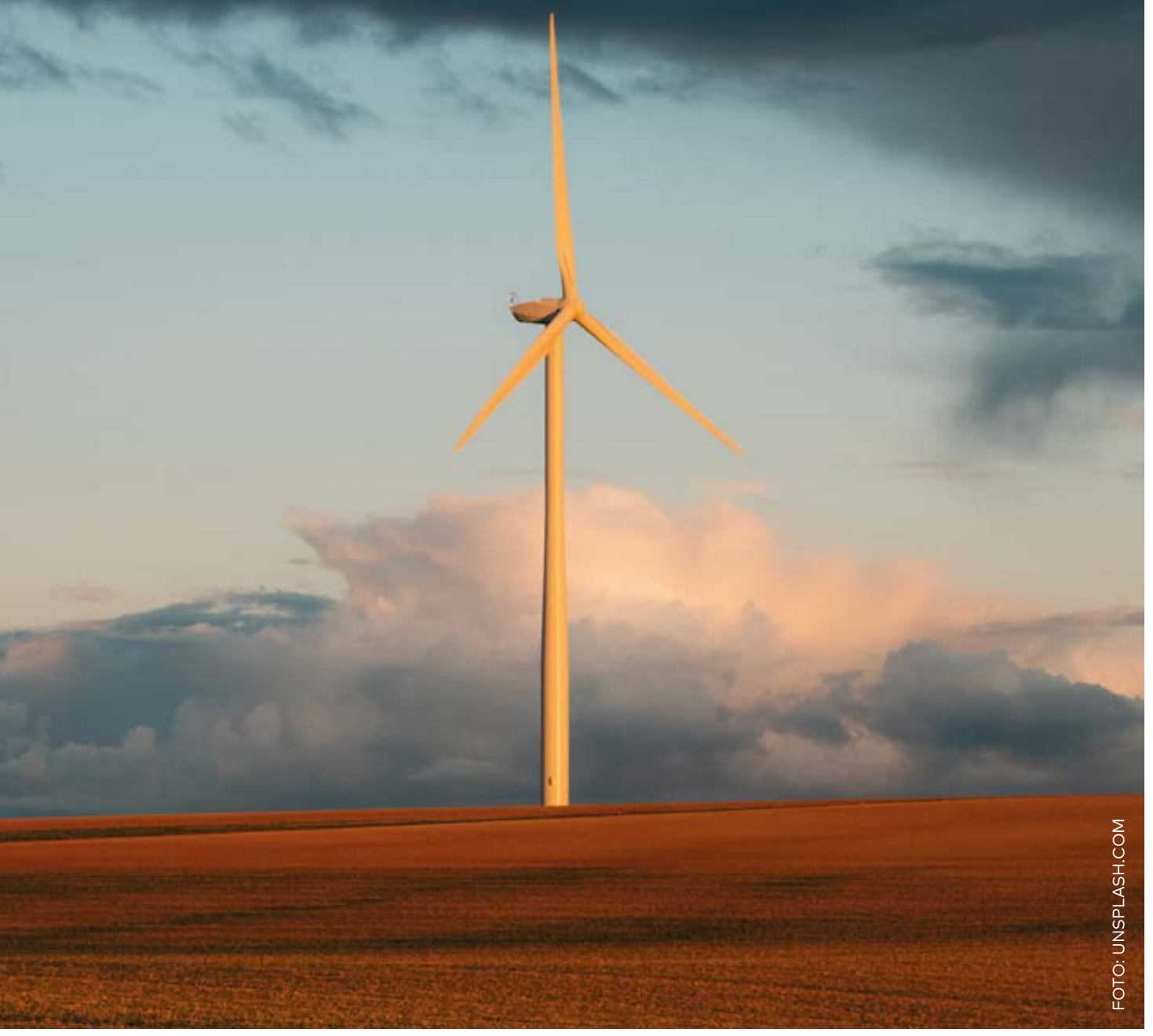




\section{The Nordic Region in Europe (EU/EEA) and other international co-operation}

Questions related to the EU/EEA and other international energy issues have been on the agenda since the beginning of official Nordic energy co-operation, which arose around the same time that the Nordic countries were choosing to pursue different forms of European cooperation through membership of the EU (Finland, Sweden and Denmark) and EEA/EFTA (Iceland and Norway).

Over the years, energy co-operation has been woven into a range of bilateral and multilateral initiatives. In many of the international arenas in which the Nordic countries are represented, it is natural and appropriate to promote Nordic cooperation and coordinate positions.

\section{The Nordic Region in Europe}

The ambition of developing the Energy Union, as well as the associated proposals for a new regulatory framework, which are now in the decision-making and implementation stages, are expected to be crucial for future Nordic work on energy policy issues. As a consequence, EU energypolicy processes and initiatives have an increasingly significant impact on the Nordic Region. This is the case for all of the Nordic countries, irrespective of whether they are EU member states. Norway and Iceland do not participate directly in negotiations on EU energy policy, but are affected by new legislation via the EEA Agreement.
While Nordic energy co-operation in the period 2014-2017 took account of policies, directives and regulations in the run-up to 2020, future Nordic energy co-operation must closely follow the decision-making and implementation process that began in the $\mathrm{EU}$ as part of the work on new targets for 2030.

The Nordic Energy Co-operation Programme for 2018-2021 will coincide with the completion of negotiations on a wide range of EU legislation, as well as the early stages of new legislation aimed at implementing the EU's headline targets for 2030 .

EU work on the Energy Union has given rise to significant modernisation and upgrading of regulations aimed at meeting the EU's 2030 climate targets. In particular, the Winter Package, which comprises eight separate pieces of legislation, has potential for Nordic energy co-operation.

The contacts that have been established with the Baltic countries, including in the $E U$, will continue during the new programme period. The Nordic countries will also invite the Baltic states to selected events of common interest. The co-operation with the Baltic countries has largely been developed at conferences, especially on issues related to EU energy policy. 
The co-operation with neighbouring countries, particularly with the three Baltic states, will be further developed through both the Baltic Energy Market Interconnection Plan (BEMIP) and separate Nordic initiatives. Closer cooperation on energy technology with the Baltic states will also be assessed on the basis of NEF's work with Baltic Energy Technology Perspectives.

The ambition for the new programme period is to speak actively with a Nordic voice in both formal and informal forums. This is particularly the case in the EU/EEA and other forums with Nordic participation such as BEMIP, the Pentalateral Energy Forum, the North Sea Countries Offshore Wind Initiative and the Baake initiative, etc., but also in forums where agencies such as system operators and independent regulatory authorities participate in various forms of regional co-operation.

\section{Other international co-operation}

The Nordic countries also participate in global co-operation on energy policy, e.g. via the International Energy Agency (IEA) and the International Renewable Energy Agency (IRENA). In an international context, it can be useful for the Nordic Region to act together in areas of obvious shared interest and where joint action can be planned. The IEA and NEF's technological report, Nordic Energy
Technology Perspectives (NETP), shows that the Nordic countries are at an advanced stage in the green transition and have a number of positions of strength that it would be an advantage to implement at global level, in terms of both exports and the promotion of joint Nordic political positions.

The prime ministers' 2017 initiative for Nordic global energy solutions will be an area of focus during the programme period. One focal point will be co-operation with the Nordic business community on building up and maintaining Nordic positions of strength and exports.

At the 2016 meeting of energy ministers, a Nordic initiative was launched with the aim of bringing the Clean Energy Ministerial/Mission Innovation (CEM9/ MI-3) to the Nordic Region in 2018. This is a highly successful example of the way in which Nordic energy co-operation can support and develop global initiatives. Similarly, joint hosting can be used to put Nordic priorities on the international energy-policy agenda and present Nordic solutions and technologies. Closer Nordic co-operation will ensure not only the hosting of future summits and conferences, but also the maintenance and expansion of the Nordic Region as a major global player in the green transition. 


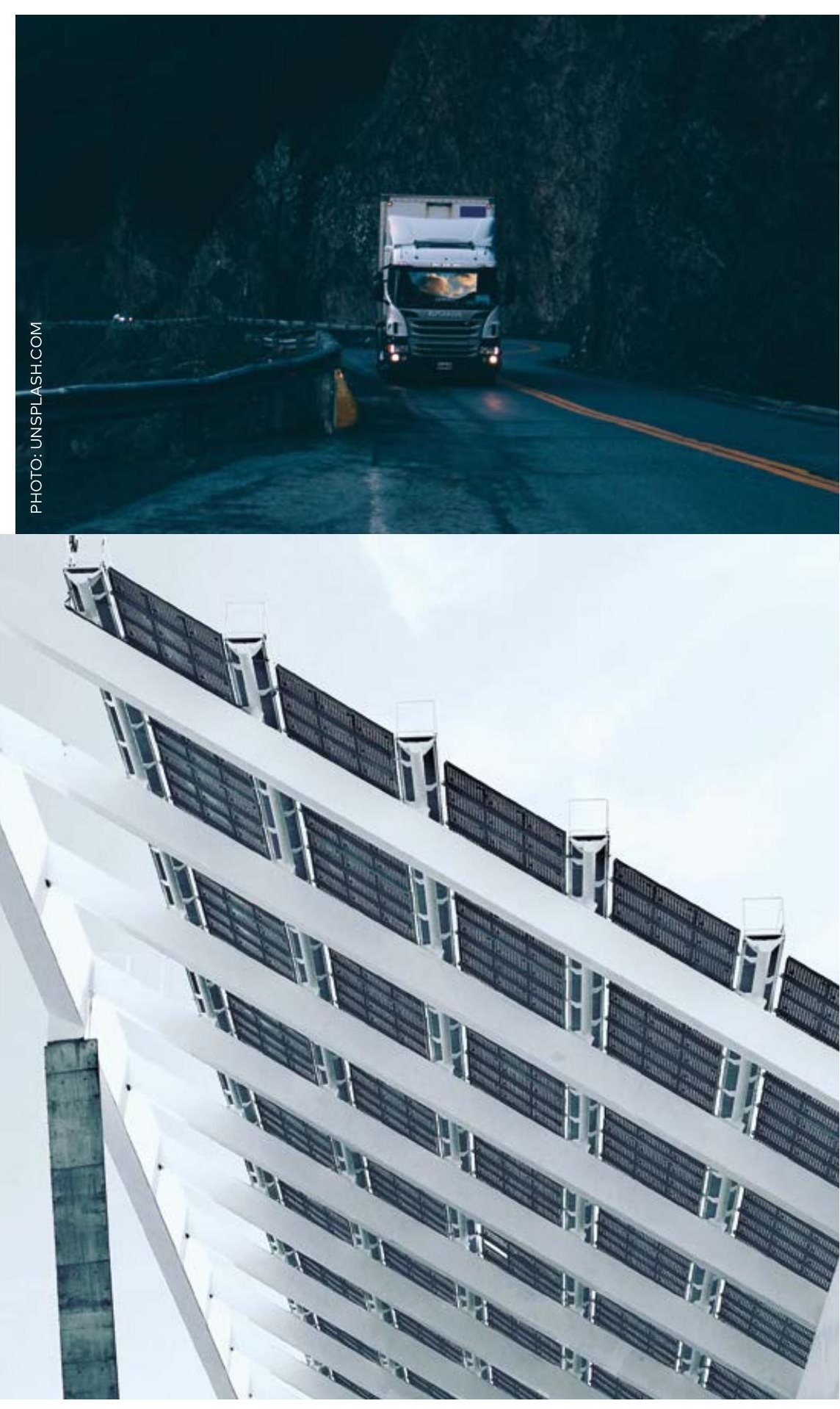




\section{Horizontal themes}

\section{Energy-related transport aspects}

The transport sector is absolutely central to achieving the primary national objectives on climate and energy policy, not least because this is the sector that uses most fossil fuels. Close Nordic cooperation in this sector will, therefore, be absolutely necessary in order to achieve the objectives. During the new programme period, the priority will be to establish closer co-operation.

An efficient transport system requires effective technical solutions and crossborder co-operation. Such co-operation will also be crucial for the industry's ability to develop and test new solutions. The strategic review's proposals for a common approach to transport and the use of the whole Nordic Region as a test bed for new technologies will be part of the work of strengthening Nordic energy co-operation in the transport sector.

However, as a horizontal theme, cooperation on transport is inherently challenging. Adding borders into the equation does not make the work any easier. As a result, closer energy cooperation on transport will primarily focus on parts of the sector that are considered to have the closest connection to the energy sector, e.g. electrification and the use of biofuels (and biogas) for land, shipping and air transport. The focus will be on issues of common interest, such as standardisation, infrastructure, information, instruments, business models, the impact on the single Nordic electricity market, etc.

One additional impetus for closer Nordic co-operation on energy in transport may be the implementation of the EU's proposed revision of the Directive on Promotion of the Use of Energy from Renewable Sources (the RES Directive), ${ }^{8}$ which includes the transport sector.

A natural starting point for the work can be found in the existing activities under the auspices of NEF. Technical input from this work will inform closer co-operation/coordination between national policies in the area. This will promote Nordic positions of strength and provide a stronger foundation for the effective fulfilment of ambitious national climate objectives.

\footnotetext{
${ }^{8}$ Negotiations on changes to the European Parliament' and Council's Directive on the promotion of the use of energy from renewable sources (revision of the Renewable Energy Directive) had not been completed at the time this programme was adopted.
} 


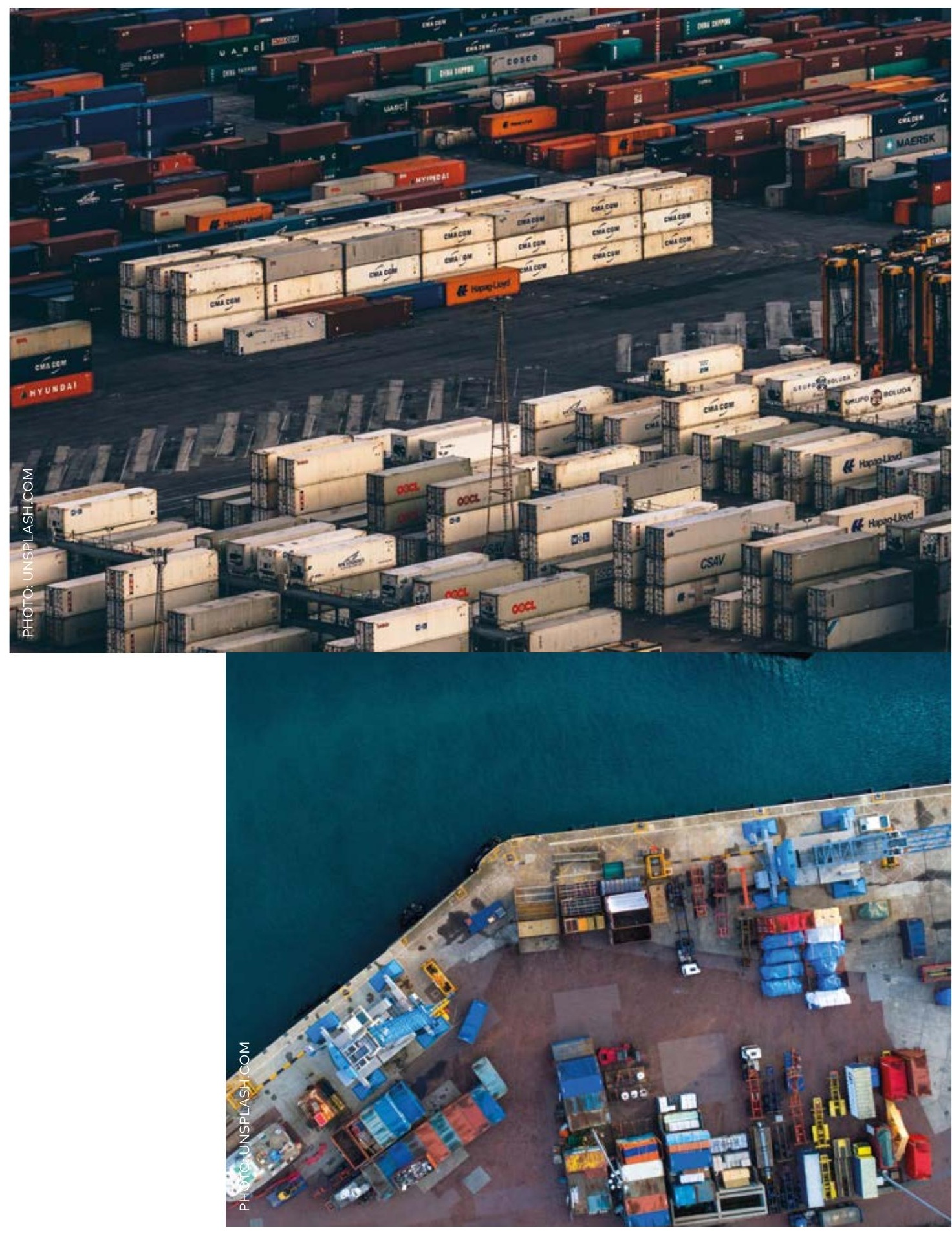


As part of the energy sector's work on transport issues, another ambition will be to establish closer co-operation with other sectors and stakeholders in the transport sector. The way that this cooperation is organised will be evaluated.

\section{Nordic energy co-operation in the Faroe Islands, Greenland and Åland}

In recent years, the Nordic Council of Ministers has focused on strengthening the Nordic countries' efforts to ensure access to sustainable and renewable energy. This, of course, also applies to Greenland and the Faroe Islands. Åland is already part of the single Nordic electricity market, and one of the activities it is involved in is the development of smart electricity systems. The focus will also be on the potential of supporting these areas' priorities and strategic agendas, and on increasing Nordic added value through synergies. In this way, the Nordic cooperation will be able to accommodate different national and global energy and environmental challenges.

The ambition is that areas outside of the central Nordic energy grid should be an integral part of Nordic co-operation on energy policy. Energy supply in these areas must be secure, environmentally friendly and from renewable sources.
The ambition is for the Nordic Region to be a leader in the green transition. This will require Nordic energy cooperation contributing with concrete, solution-oriented activities tailored to local challenges, including in areas not connected to the single Nordic electricity market/electricity grid. This work must be based on innovation, research, learning, exchanges of experiences and specific co-operation projects. In this way, areas throughout the Nordic Region can be used as test beds for developing and testing new Nordic energy solutions based on their respective positions of strength. In this way, the Nordic Region can strengthen its position as a global leader in the energy area. This work can be evaluated on the basis of, e.g. NEF's work on "Energy in the West Nordic Region and the Arctic".

\section{Links to horizontal strategies}

The programme for energy co-operation contributes to the overall vision that the ministers for co-operation have for Nordic co-operation: an innovative, borderless, visible, outward-looking Nordic Region. The implementation of the co-operation programme also contributes, where appropriate, to fulfilling the Nordic Council of Ministers' three horizontal strategies on sustainable development, children and young people and gender equality, 
as well as other horizontal strategies.

Other horizontal questions will be taken up with other relevant sectors and stakeholders.

The sector will also contribute actively to fulfilling the Nordic Council of Ministers' work in connection with Agenda 2030, i.e. the UN's 17 Sustainable Development Goals (SDGs), which are expected to have a material impact on the Nordic countries in the near future. However, not all the SDGs are of equal relevance for the sector. The ones considered to be particularly relevant during the programme period are:
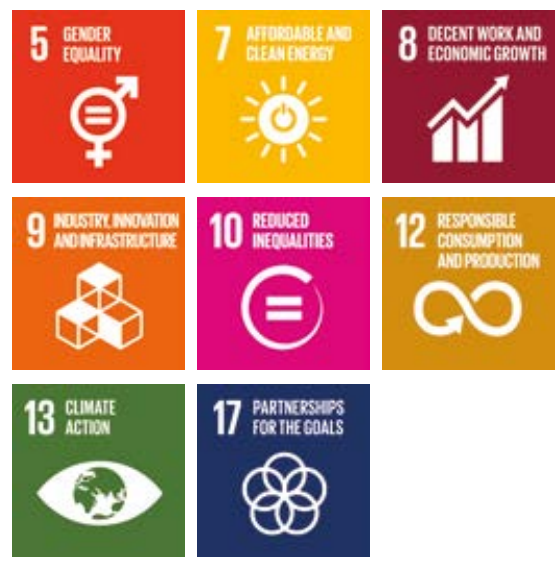

17 PARTKRESTES

17 For Hite GaAls

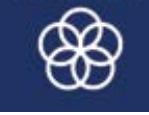




\section{Appendix A \\ The organisation of the sector}

This section describes the organisation of the sector. As of January 2018, Nordic energy co-operation will consist of the Nordic Council of Ministers for Growth (MR-Vækst) (energy), the Committee of Senior Officials for Energy Policy (EKE), Nordic Energy Research (NEF) and working groups for electricity market cooperation (EMG) and renewable energy (AGFE), as well as the Networking Group for Energy Efficiency (NGEE) and Regulatory Working Group for Nordsyn
(MANO). Nordsyn has been established at the start of this programme period as a working group for official agencies, including the regulatory authorities, under the auspices of EK-E.

The new programme will focus on enhancing co-operation, particularly between the electricity market group and the working group on renewable energy.

\section{MR-Vækst}

\section{EK-E}

\section{Working Groups:}

AGFE

EMG

\section{NEF}

Regulatory Working Group for Nordsyn: MANO

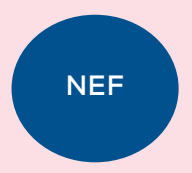

Networking Group for Energy Efficiency: NGEE 


\section{Appendix B}

\section{Strategic review of the energy sector}

In January 2016, the Nordic Council of Ministers commissioned Jorma Ollila, former CEO of Nokia, to carry out a strategic analysis of how Nordic energy co-operation might develop over the next 5-10 years. In June 2017, he presented his report to the Norwegian Minister of Petroleum and Energy, Terje Søviknes, in his role as chair of the Nordic Council of Ministers for Business, Energy and Regional Policy (MR-NER) in 2017, and to the Nordic Council of Ministers' Secretary General, Dagfinn Høybråten. The report contributes to the debate on the future of energy cooperation.

The strategic review of energy cooperation is part of the Nordic Council of Ministers' reform project, one of the aims of which is to improve the efficiency of the Council's work. The inspiration for these strategic analyses stems from the Stoltenberg report on defence and security policy.
Jorma Ollila's Report: Nordic Energy Co-operation: Strong today - stronger tomorrow contains 14 proposals for closer energy co-operation. The report is based on the transition to green energy, the Paris Climate Agreement, developments in the EU energy sector and national energy strategies in the Nordic Region.

The report provided important input to the discussions that informed this cooperation programme. A number of its recommendations have been included in the programme, in particular the vision for co-operation and energy research co-operation, and have also influenced collaboration on national energy plans.

The recommendations in the report cover both the current situation and the years to come, and as such will be regularly evaluated in order to realise a vision of a form of co-operation that meets ambitious national climate and energy policy targets. 


\section{Appendix C \\ Strategic mandate for Nordic Energy Research (NEF)}

The strategic mandate for the work of Nordic Energy Research (NEF) in the new period is to ensure coherence between this co-operation programme, NEF's articles of association and its funding document, NEF's strategy for 2018-2021 and the implementation of the Nordic Council of Ministers' budget. The results of the strategic review of the energy sector must be incorporated into considerations about the organisation's work. In general, all of NEF's activities must promote Nordic co-operation on energy, Nordic synergies and Nordic visibility.

The main objectives of Nordic energy co-operation are to contribute to stable, secure energy supply, sustainable growth and prosperity for the people of the Region, and to help face climate and environmental policy challenges. The cooperation also serves as an instrument for marketing Nordic positions of strength in the energy sector, both in Europe and around the world.

NEF's main purpose is energy research that supports Nordic co-operation on energy. Its articles of association state that NEF should work to maintain and develop the Region's positions of strength in the development and the use of competitive, sustainable energy solutions. This is the basis for NEF activities, e.g. new research projects.
There must also be a simultaneous focus on Nordic synergy, including in European and international contexts. As part of Nordic co-operation on energy research and analysis, NEF must, therefore, speak authoritatively on behalf of the whole Region. Specifically, this is done through funding and facilitating energy research, co-operation projects, scenario development and analysis in the energy sector, and by raising the profile of Nordic energy co-operation.

NEF determines its activities within the framework of four-year programmes. NEF's priorities for these programmes are determined partly on the basis of the Nordic energy co-operation programme. The overall aim of the strategic priorities for 2018-2021 is to provide a basis for the Nordic Region to become the world leader in smart energy solutions. Nordic co-operation is the means by which this will be achieved. The research cooperation will focus in particular on the green transition in electricity, heating and transport, regional networks, active end users, and studies of Nordic energy systems.

NEF is funded by the Nordic Council of Ministers and by member countries, as well as by contributions from public or private project partners. 


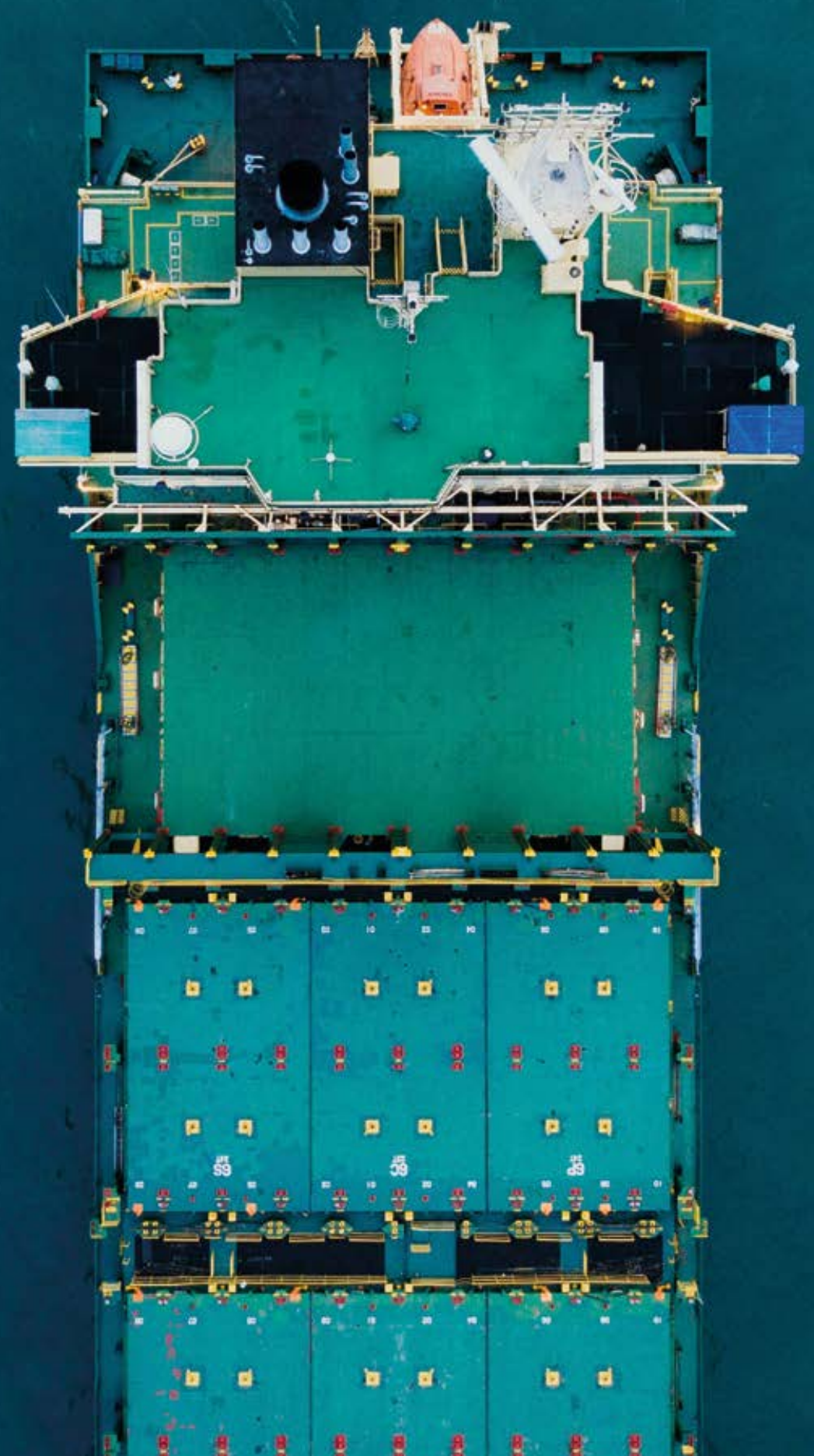




\section{$\mathbb{1}$}

Nordic Council of Ministers

Nordens Hus

Ved Stranden 18

1061 Copenhagen $\mathrm{K}$

www.norden.org

The Nordic energy ministers present a new Nordic energy policy co-operation programme for the period 2018-2021.

The vision for Nordic energy co-operation is to develop Nordic energy systems through strong, trust-based, adaptable co-operation in order to secure the world's most integrated and intelligent low-emission green economy, characterised by security of supply and a high level of competitiveness.

Nordic energy co-operation in the period 2018-2021 will specifically address the following areas:

- Further development of the Nordic electricity market

- Renewable energy

- Energy efficiency

- Exchange of information and dialogue on the Nordic countries' energy policies and strategies

- Energy research and innovation, via Nordic Energy Research

- The Nordic Region in Europe, including implementation of the EU Energy Union

- Neighbouring countries, particularly the Baltic states

- Energy-related transport issues

- The energy sector in the Faroe Islands, Greenland and Åland

- Other horizontal programmes and projects, as well as international co-operation. 